\title{
Temperature Effects on the Electrical Characteristics of BJTs and MOSFETs
}

\author{
Reiham. O. Ibrahim ${ }^{1}$, S. M. Abd El-Azeem ${ }^{1}$, S. M. El-Ghanam ${ }^{1}$ and F. A. S.Soliman ${ }^{2}$ \\ 1- Electronic Res. Lab., Physics Dept., Faculty of Women for Arts, \\ Science and Education, Ain-Shams Univ., Cairo, Egypt. \\ 2- Nuclear Materials Authority, P. O. Box 530-Maadi-11728, Cairo, Egypt. \\ *Corresponding author: E-mail address: reihamosama@gmail.com
}

\begin{abstract}
The aim of the present paper is to shed further light on studying the temperature effects on the static (I-V) and dynamic (C-V) characteristics of bipolar junction- and metal oxide field effect - transistors. In this concern, several parameters were plotted at different temperature levels. The experimental results showed that, for the bipolar junction transistor 2SC2120, a noticeable increase in the collector current and the current gain from $0.198 \mathrm{~A}$ and 0.14 up-to $0.25 \mathrm{~A}$ and 0.24 by increasing the temperature from $25^{\circ} \mathrm{C}$ and $135^{\circ} \mathrm{C}$, respectively. Considering the threshold voltage, its value was shown to be decreased from 0.62 Volt to 0.42 Volt within the same temperature range. In addition, from the traced dynamic characteristics of the same BJT, the diffusion capacitance of the emitter-base junction, as an example, increased from $10.11 \mathrm{nF}$ up-to $45.09 \mathrm{nF}$ by increasing the temperature up-to $135{ }^{\circ} \mathrm{C}$. On the other hand, for metal oxide field effect transistor $2 \mathrm{~N} 6660$, the static characteristics showed that a noticeable decrease in the drain current and the forward trans-conductance from $1.2 \mathrm{~A}$ and $5.0 \Omega^{-1}$ down-to $0.79 \mathrm{~A}$ and $1.9 \Omega^{-1}$, respectively, due to temperature increasing from $25^{\circ} \mathrm{C}$ up-to $135^{\circ} \mathrm{C}$. While the threshold voltage was hold constant. Finally, the reverse capacitance of the gate-drain junction was shown to be increases from $41.48 \mathrm{pF}$ up-to $47.31 \mathrm{pF}$ within the same range of temperature.
\end{abstract}

Keywords: Temperature effect, bipolar junction transistor, metal oxide field effect transistor, capacitance, impedance, quality and dissipation factor and phase angle.

\subsection{Introduction}

Temperature is one of the most common keys design factors in electronic designs. Designers must confirm that semiconductor devices operate correctly across a wide range of temperatures [T. D. Haeffner, 2015]. Temperature can change the operation of semiconductor devices significantly. To make the design of some application possible as an example, biomedical applications, such as breathing sensors, temperature sensors and other applications, the temperature characteristics of the transistors must be considered [S. Bethi, et al, 2014]. In this concern, the present paper targets to study the electrical parameters for two of the most commonly two used electronic devices, namely: NPN bipolar junction Si-transistor (BJT) and Nchannel enhancement mode MOSFET under the influence of different levels of temperature. 


\subsection{Experimental Work}

The experimental work was based on studying the electrical parameters of NPN (BJT) type 2SC2120 and N-channel enhancement mode MOSFET type 2N6660 under the influence of wide temperature levels, ranging from $25^{\circ} \mathrm{C}$ up-to $135^{\circ} \mathrm{C}$. In this concern, $370 \mathrm{~A}$ Tektronix curve tracer system and programmable automatic Fluke PM6306 RCL bridge were applied for precise measurements.

\subsection{Results and Discussions}

\subsection{Static Characterization of Transistors} 3.1.1. Bipolar junction transistors

The output characteristic curves (collector current $\mathrm{I}_{\mathrm{C}}$, collector-emitter voltage $\mathrm{V}_{\mathrm{CE}}$, of the $\mathrm{Si}$ 2SC2120 transistor were plotted at base current $\mathrm{I}_{B}$ value of $1 \mathrm{~mA}$, under the influence of different temperature levels, ranging from $25^{\circ} \mathrm{C}$ up-to $135^{\circ} \mathrm{C}$ Fig. (1). It is clearly shown that, $\mathrm{I}_{\mathrm{C}}$ increases as a function of temperature level, where at $\mathrm{V}_{\mathrm{CE}}=3$ Volts, $\mathrm{I}_{\mathrm{C}}$ reaches a value of $0.25 \mathrm{~A}$, measured at $135{ }^{\circ} \mathrm{C}$, while its initial value was $0.198 \mathrm{~A}$, measured at $25^{\circ} \mathrm{C}$ [A. S. Sedra, 2004, N. Rinaldi and V. Alessandro,2005].

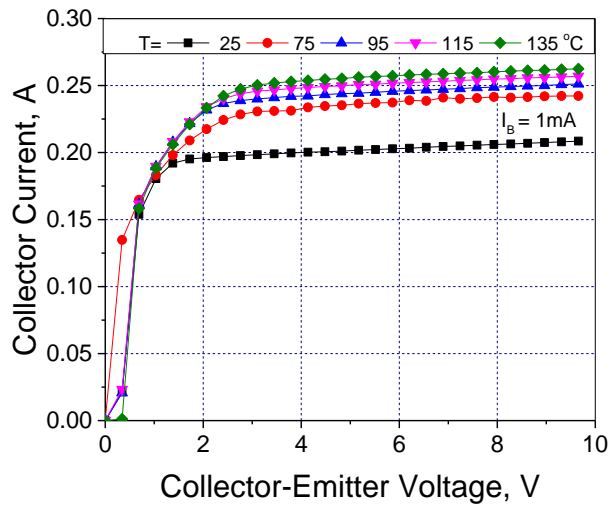

Fig. (1): Dependence of the output characteristics curve on temperature for BJT type 2SC2120.

Besides, the output-resistance $\left(\mathrm{R}_{\text {out }}\right)$ of BJT's was calculated for the different temperature levels using Eq. (1) and the dependence of its value on temperature was shown in Fig. (2a) [B.L. Theraja, 2008, J. Millman and C.C. Halkias, 1972]. From which, it is shown that $\mathrm{R}_{\text {out }}$ decreased from an initial value of $15 \Omega$, measured at $25^{\circ} \mathrm{C}$ down-to $8.54 \Omega$, at $135^{\circ} \mathrm{C}$, after that saturation conditions was observed.

$$
\mathrm{R}_{\mathrm{out}}=\frac{\Delta V_{C E}}{\Delta I_{C}}
$$

Where,

$\Delta \mathrm{V}_{\mathrm{CE}}$ : Change in collector-emitter voltage and

$\Delta \mathrm{I}_{\mathrm{C}}$ : Change in collector current. 
Also, dc current gain $\left(\mathrm{h}_{\mathrm{FE}}\right)$ was calculated applying Eq. (2) and plotted as function of temperature Fig. (2b) [A. S. Sedra, 2004, B.L. Theraja, 2008 and J. Millman and C.C. Halkias, 1972]. From which, it is clear that, $\mathrm{h}_{\mathrm{FE}}$ increased from an initial value of 0.14 , measured at $25^{\circ} \mathrm{C}$ up-to 0.239 , at $135{ }^{\circ} \mathrm{C}$, and at the end, saturation conditions was observed.

$$
\mathrm{h}_{\mathrm{FE}}=\frac{\Delta I_{C}}{\Delta I_{B}}
$$

Where;

$\Delta \mathrm{I}_{\mathrm{C}}$ : Change in collector current and

$\Delta \mathrm{I}_{\mathrm{B}}$ : Change in base current

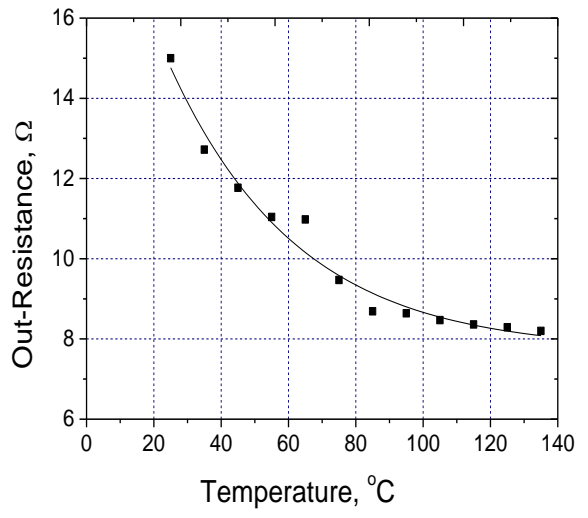

(a)

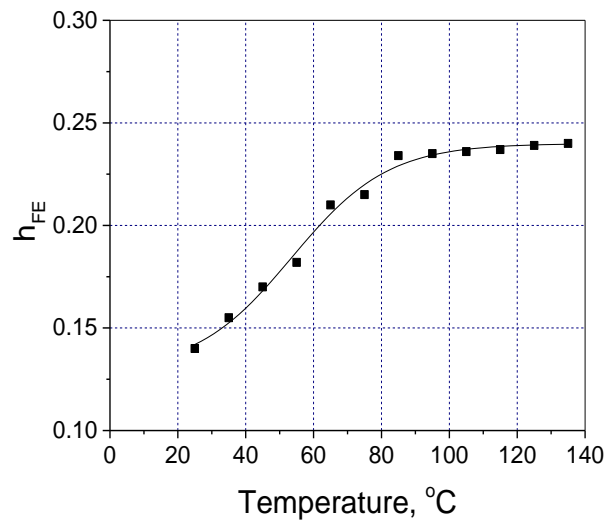

(b)

Fig. (2): Temperature dependence of the dc current gain (a) and output-resistance (b) of BJT type $2 \mathrm{SC} 2120$.

In addition, the study was extended to include the temperature effect on the input characteristics of the investigated transistor. Where, Fig. (3a) shows a set of $\left(\mathrm{I}_{\mathrm{B}}-\mathrm{V}_{\mathrm{BE}}\right)$ curves plotted_within the temperature range from $25{ }^{\circ} \mathrm{C}$ up-to $135^{\circ} \mathrm{C}$. As a result, the dependence of the threshold voltage $\left(\mathrm{V}_{\mathrm{Th}}\right)$ on temperature was shown in Fig. (3b). From which, $\mathrm{V}_{\mathrm{Th}}$ value was shown to be decreased from 0.62 Volt down-to $0.42 \mathrm{Volt}$, in the temperature range from $25^{\circ} \mathrm{C}$ up-to $135{ }^{\circ} \mathrm{C}$, this is mainly due to the fact that the increasing temperature leads the electrons in the valance band to be excited, pulling them into the conduction band, resulting an increase in the current. The temperature dependence was shown to be linear decay, following the relation [B. Eslamia and S. Ashrafib, 2016, E. Schurackm, et al, 1992 and Yam Agiwa, et al, 2008]:

$$
V_{T h}(T)=V_{T h}(0)-A T
$$

Where;

$\mathrm{V}_{T h}(\mathrm{~T})$ and $\mathrm{V}_{\mathrm{Th}}(0)$ : threshold voltages (Cut-in voltage), measured at measuring-and room-temperature level, respectively.

A: slope of the dependence, and

$\mathrm{T}$ : temperature 


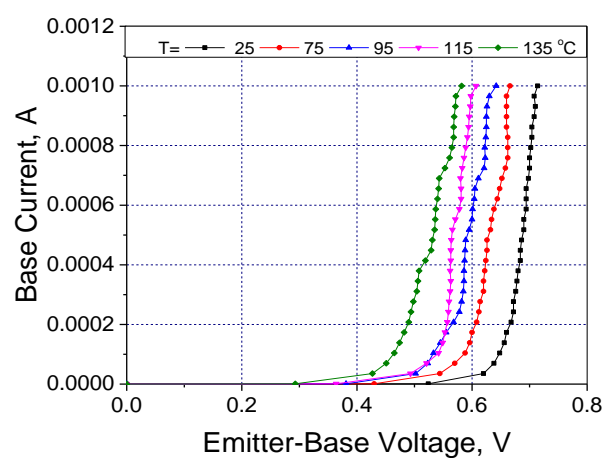

(a)

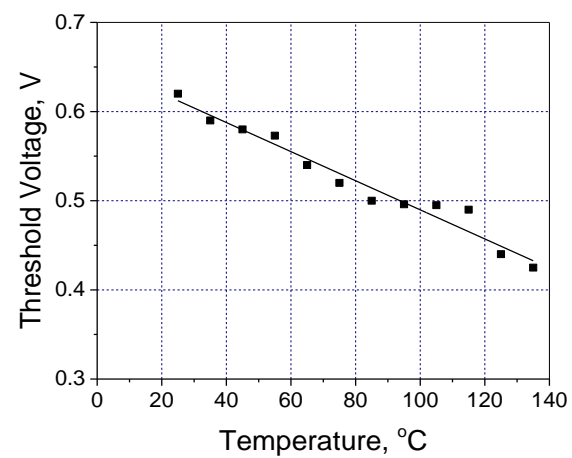

(b)

Fig. (3): Temperature dependence of input curves (a) and threshold voltage (b) for BJT 2SC2120.

\subsubsection{Metal Oxide Field Effect Transistor}

The static characteristics (output and transfer) of MOSFET type 2N6660 were investigated. In this concern, the output characteristic curves of the investigated MOSFET (drain current $I_{D}$ as a function of drain-to-source voltage, $\mathrm{V}_{\mathrm{DS}}$ ) was studied and plotted at gate-to-source voltage $\left(\mathrm{V}_{\mathrm{GS}}\right.$ ) value of 3 Volts for different temperature levels, ranging from $25^{\circ} \mathrm{C}$ up-to $135^{\circ} \mathrm{C}$ as shown in Fig. (4). From which, Fig. (5a) shows $\mathrm{I}_{\mathrm{D}}$ as a function of temperature. It was found that, $\mathrm{I}_{\mathrm{D}}$ was shown to be decreased from $0.219 \mathrm{~A}$, measured at $25^{\circ} \mathrm{C}$, down- to $0.158 \mathrm{~A}$, measured at $135^{\circ} \mathrm{C}$.

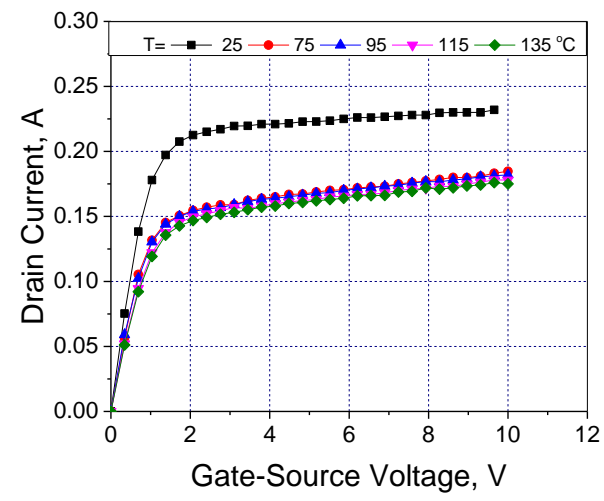

Fig. (4): Temperature dependence of the output characteristics of MOSFET 2 N6660.

As it is well known that, every MOSFET device has a resistive element known as ON resistance $\left(R_{\text {on }}\right)$ and can be calculated using the following [B.L. Theraja, 2008, H. Djelti. et al, 2008 and J. Millman and Ch.C. Halkias, 1972]:

$$
\boldsymbol{R}_{\mathrm{on}}=\frac{\Delta V_{D S}}{\Delta \boldsymbol{I}_{D}}
$$

Where,

$\Delta \mathrm{V}_{\mathrm{DS}}$ : Change in drain-source voltage and

$\Delta \mathrm{I}_{\mathrm{D}}$ : Change in drain current 
In this concern, the temperature effect on $\mathrm{R}_{\text {on }}$ was considered (Fig.5b). From which, It is shown that, $R_{\text {on }}$ increased from an initial value of $5.77 \Omega$ measured at $25^{\circ} \mathrm{C}$ up-to $11 \Omega$ at $135^{\circ} \mathrm{C}$

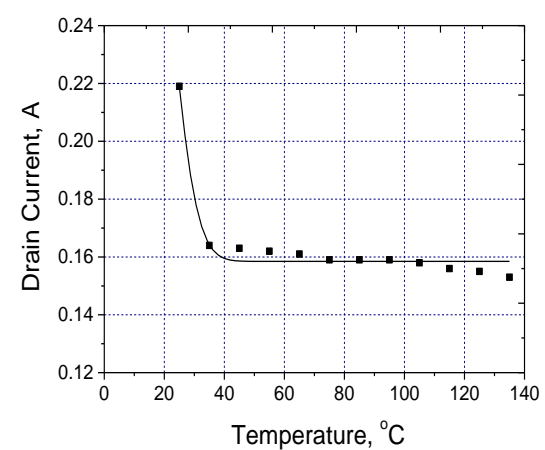

(a)

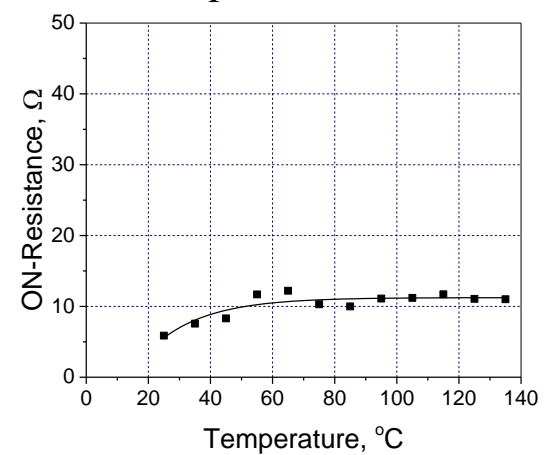

(b)

Fig. (5): Temperature dependence of the drain current (a) and ON-resistance (b) of MOSFET 2N6660.

Figure (6) shows the transfer characteristics $\left(\mathrm{I}_{\mathrm{D}}-\mathrm{V}_{\mathrm{GS}}\right)$ of the investigated MOSFET, plotted at different temperature levels Fig. (6a), where the measurements were carried out within the temperature range from $25^{\circ} \mathrm{C}$ up-to $135^{\circ} \mathrm{C}$. As a result, the dependence of the threshold voltage $\left(\mathrm{V}_{\mathrm{Th}}\right)$ on temperature was shown in Fig. (6b). From which, it is clearly shown that the threshold voltage isn`t affected by the temperature variations [H. Djelti. et al, 2008].

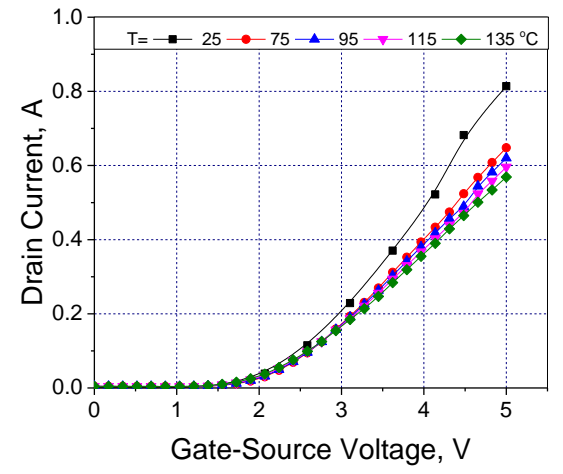

(a)

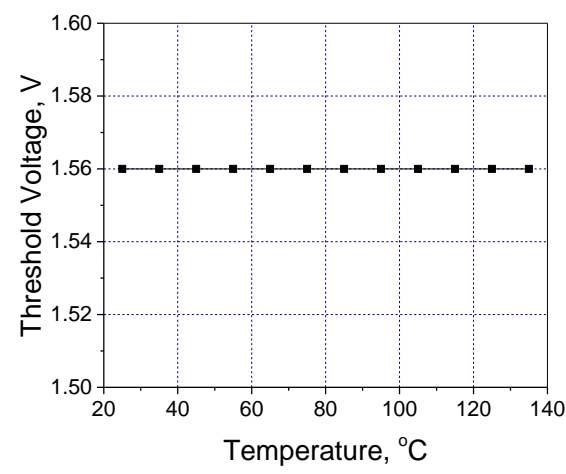

(b)

Fig. (6): Temperature dependence of the transfer characteristic curves (a) and threshold voltage (b) for MOSFET type 2 N6660.

In addition, the forward trans-conductance $\left(\mathrm{g}_{\mathrm{fs}}\right)$ was calculated using Eq.(5), and plotted as function of temperature [B.L. Theraja, 2008] as shown in Fig. (7). It is clear that $\mathrm{g}_{\text {fs }}$ was decreased from $0.292 \Omega^{-1}$ down-to $0.215 \Omega^{-1}$, whenever the devices were exposed to temperature within the investigated range [A.A. Osman and M. A. Osman, 1998].

$$
\mathrm{g}_{\mathrm{fs}}=\frac{\Delta I_{D}}{\Delta V_{G S}}=
$$

Where,

$\Delta \mathrm{I}_{\mathrm{D}}: \quad$ Change in drain current and

$\Delta \mathrm{V}_{\mathrm{GS}}$ : Change in gate-source voltage. 


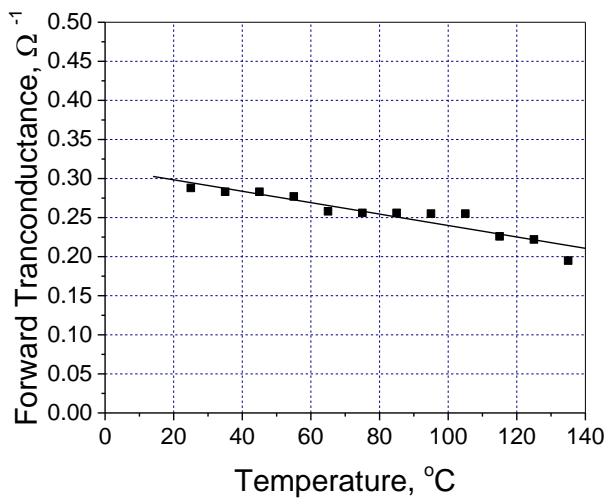

Fig. (7): Temperature dependence of the forward trans-conductance for MOSFET type 2N6660.

\subsection{Dynamic Characterization of Transistors 3.2.1. Bipolar junction transistors}

The dependence of both the diffusion $\left(\mathrm{C}_{\mathrm{d}}\right)$ and transition $\left(\mathrm{C}_{\mathrm{T}}\right)$ capacitances, for emitter- and collector- base junctions of BJT type $2 \mathrm{SC} 2120$ on temperature (in the range from $25{ }^{\circ} \mathrm{C}$ up-to $135{ }^{\circ} \mathrm{C}$ ) was shown in_Fig. (8). From which, it is clear that $\mathrm{C}_{\mathrm{d}}$, for both emitter- and collector- base junctions increased from $10.11 \mathrm{nF}$ up-to $45.09 \mathrm{nF}$ and from $11.2 \mathrm{nF}$ up-to $54.5 \mathrm{nF}$, respectively measured at the temperature range from $25{ }^{\circ} \mathrm{C}$ up-to $135{ }^{\circ} \mathrm{C}$. While for the $\mathrm{C}_{\mathrm{T}}$, it is clearly shown that, a noticeable increase on the capacitance value, from $0.21 \mathrm{nF}$ up-to $0.68 \mathrm{nF}$ for the emitter-base and for the collectorbase junction from $0.177 \mathrm{nF}$ up-to $0.69 \mathrm{nF}$ [H. Mnif, et al, 2002].

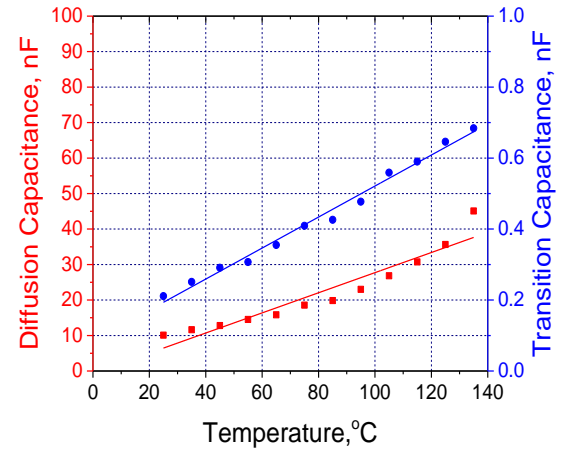

(a)

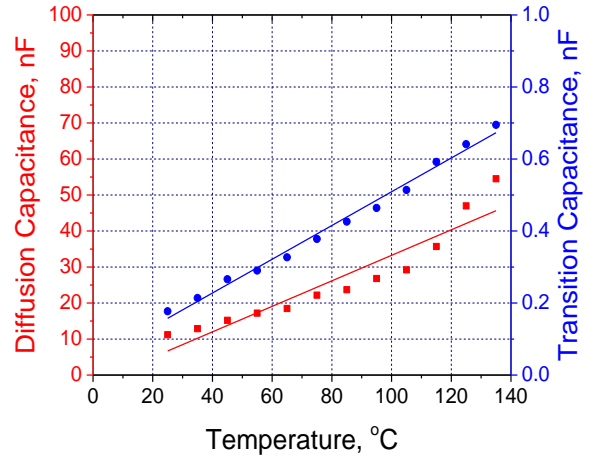

(b)

Fig. (8): Temperature dependences of diffusion- and transition- capacitance of the emitter-base- (a) and collector-base- (b) junctions for BJT 2SC2120.

Moreover, Fig. (9) shows the effect of temperature on the impedance (Z) of the emitter- and collector- base junctions, for both the forward and reverse bias directions, plotted at the same temperature levels. It is clear a pronounced decrease on the impedance values of both bias directions was observed. Where, for the forward emitter- and collector- impedance a values of $35.98 \mathrm{k} \Omega$ and $35.84 \mathrm{k} \Omega$, measured at $25^{\circ} \mathrm{C}$, were shown to be decreases down-to $12.52 \mathrm{k} \Omega$ and $12.76 \mathrm{k} \Omega$, measured at $135{ }^{\circ} \mathrm{C}$, respectively. On the other hand, for the reverse emitter- and collector- impedance, values of $10.7 \mathrm{k} \Omega$ and $10.2 \mathrm{k} \Omega$, measured at $25{ }^{\circ} \mathrm{C}$, were shown to be decreased down-to $2.09 \mathrm{k} \Omega$ and $1.2 \mathrm{k} \Omega$, measured at $135^{\circ} \mathrm{C}$. 


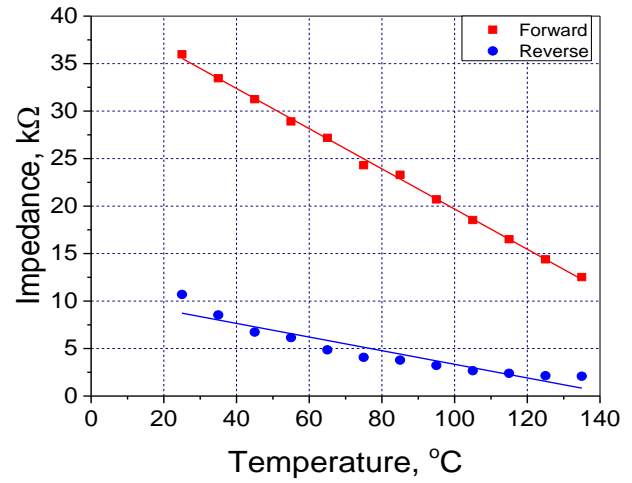

(a)

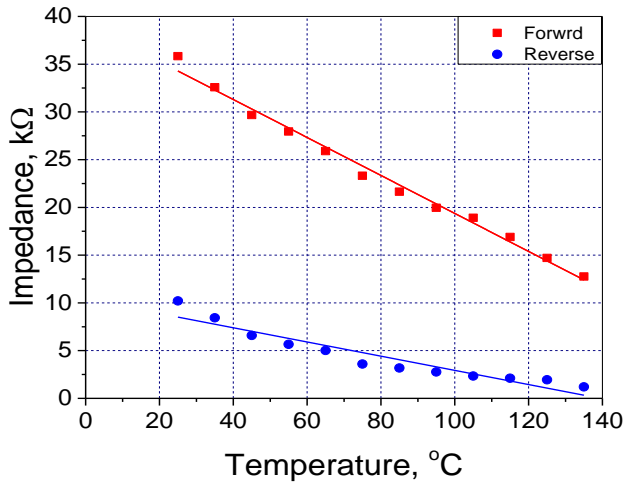

(b)

Fig. (9): Temperature dependences of forward- and reverse- impedances of the emitter-base- (a) and collector-base- (b) junctions for BJT 2SC2120.

Figure (10) shows the effect of temperature on the quality factor $(\mathrm{Q})$, plotted at both the forward and reverse bias directions of the emitter-base junction of BJT 2SC2120. From which, a pronounced increase in its value was observed for the forward bias, where a value of 0.092 , measured at $25{ }^{\circ} \mathrm{C}$, was shown to be increased up-to 0.16 , at $135^{\circ} \mathrm{C}$. On the other hand, for the reverse bias, a pronounced decrease on $\mathrm{Q}$ value from 0.74 down-to 0.37 , for the same range of temperature levels. Also, the same figure shows the effect of temperature on dissipation factor (D) for the forward and reverse bias of the emitter-base junction. It is clear that, for the forward bias, a pronounced decrease in D value was observed, where it was shown to be decreased pronouncedly from 10.88 , measured at $25{ }^{\circ} \mathrm{C}$ down-to 5.5 , measured at 135 ${ }^{\circ} \mathrm{C}$. While, for the reverse bias, its value increased from 1.33 up-to 2.66 was reported in the same temperature range [R. M. Fox and S. G. Lee, 1991].

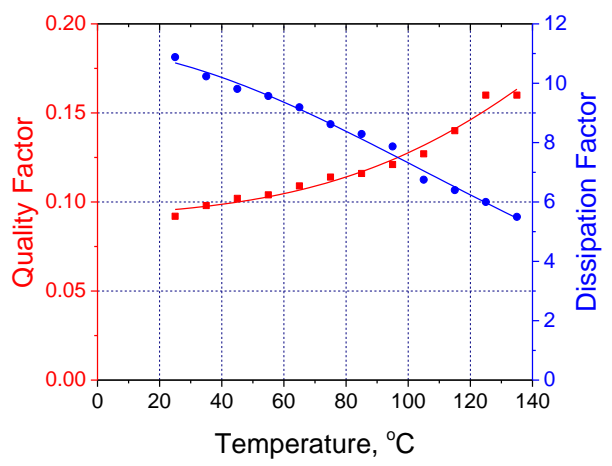

(a)

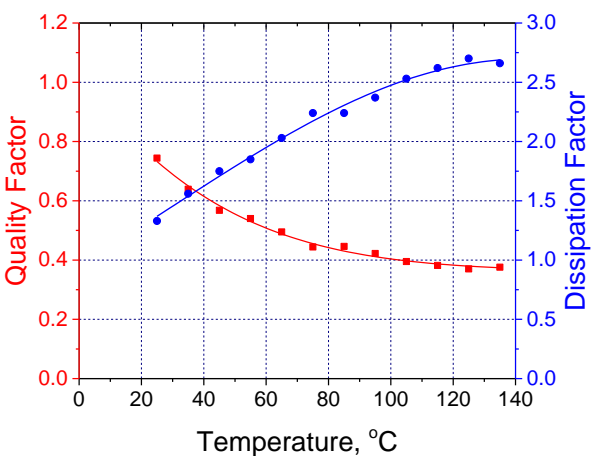

(b)

Fig. (10): Temperature dependences of the emitter-base junction forward (a) - and reverse (b) - quality and dissipation factors of the BJT 2SC2120.

For the forward Q of collector-base junction Fig. (11a), a pronounced increase in its value was observed, where a value of 0.1 measured at $25^{\circ} \mathrm{C}$, was shown to be increased up-to 0.21 , at $135^{\circ} \mathrm{C}$. On the other hand, for the reverse Q of collector-base junction (Fig. 11b). It is clearly shown that, starting from $25^{\circ} \mathrm{C}$ up-to $135^{\circ} \mathrm{C}$, a pronounced decrease on its value from 0.56 down-to 0.36 for the same range of temperature levels. Besides, the effect of temperature on both the forward and reverse $\mathrm{D}$ of the collector-base junction of the investigated BJT in the temperature range from $25^{\circ} \mathrm{C}$ up-to $135^{\circ} \mathrm{C}$. It is clear that both of forward and reverse D are a direct function of temperature level. For the forward D, a pronounced decreased in its value was 
observed, where it decrease pronouncedly from 9.86 down-to 6.57 , measured at $25{ }^{\circ} \mathrm{C}$ and 135 ${ }^{\circ} \mathrm{C}$, respectively. On the other hand, for the reverse D, it is clearly shown that, starting from 25 ${ }^{\circ} \mathrm{C}$, an increase in its value, from 1.83 up-to 2.75 was reported [M. A. Hopcroft, et al, 2007].

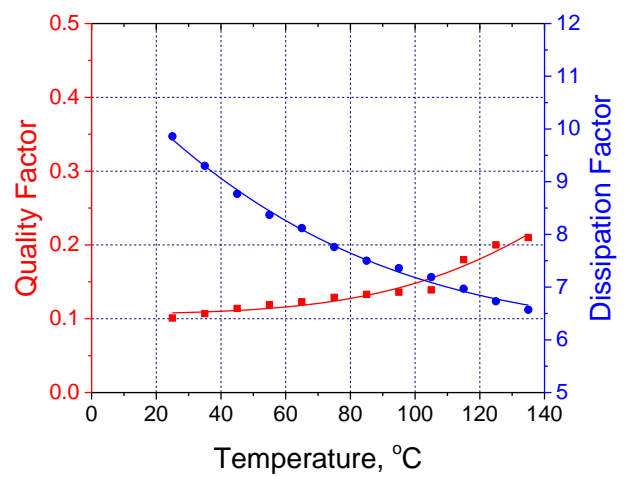

(a)

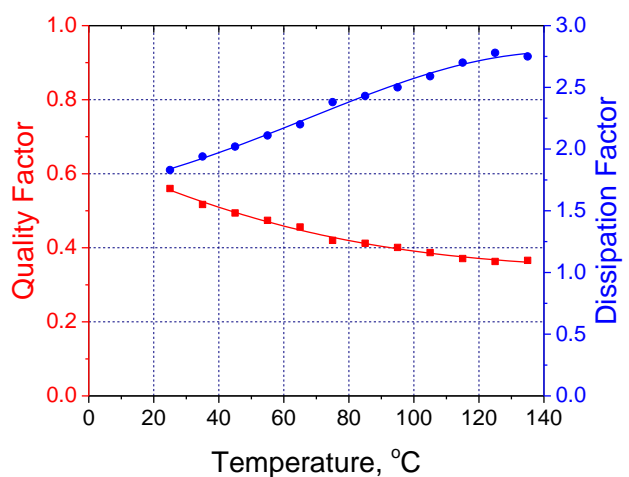

(b)

Fig. (11): Temperature dependences of the collector-base junction forward (a)- and reverse (b)- quality and dissipation factors of the BJT type 2SC2120.

The phase angle $(\phi)$ of emitter- and collector- base for BJT, as a function of temperature levels was plotted for the forward bias condition (Fig.12a), $\phi$ shows decreasing dependence on temperature, where its value decreased from $-5.3^{\circ}$ down-to $-9.2^{\circ}$ for emitter-base junction and for the collector-base it`s value was shown to be decreased from $-5.8^{\circ}$ to $-10.7^{\circ}$. On the other hand, for the reverse bias direction, $\phi$ value was shown to be increased from $-36.9^{\circ}$ up-to $-20.3^{\circ}$ and for the collector-base increased from $-29.5^{\circ}$ upto $-20.3^{\circ}$ for the same range of temperature levels.

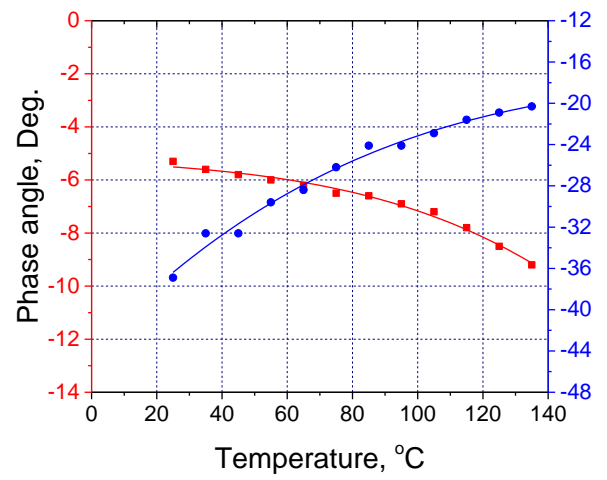

(a)

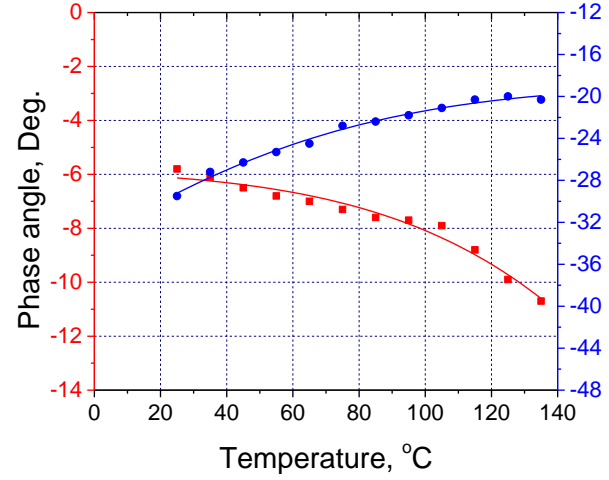

(b)

Fig. (12): Temperature dependences of forward- and reverse- phase angle of the emitter-base-(a), and collector-base-(b) junctions for BJT type 2SC2120. 


\subsubsection{Metal Oxide Field Effect Transistor}

The temperature dependence of junction capacitance for the investigated MOSFET was studied and plotted. In this concern, the drain-source, gate-drain and gate-source junction capacitances of MOSFET type 2N6660 were studied and plotted as function of temperature Fig. (13a). From which, it is clearly shown that, the drain-source capacitance decreased from 66.91 $\mathrm{pF}$, measured at $25{ }^{\circ} \mathrm{C}$, down to $15.48 \mathrm{pF}$ at $135^{\circ} \mathrm{C}$. On the other hand, for the reverse capacitance, its value was shown to be increased from $41.48 \mathrm{pF}$ up-to $47.31 \mathrm{pF}$ with increasing temperature from $25{ }^{\circ} \mathrm{C}$ up-to $135{ }^{\circ} \mathrm{C}$. Moreover, for gate-source junction capacitance, it is clearly shown that, the junction capacitance decreased with increasing temperature from 102.22 $\mathrm{pF}$ down-to $96.13 \mathrm{pF}$. In addition, the temperature dependence of junction impedance $(\mathrm{Z})$ for drain-source, gate-drain and gate-source junctions of MOSFET device are shown in Fig. (13b). From which, it is obviously shown that for the drain-source junction $\mathrm{Z}$ values was shown to be decreased from $0.63 \mathrm{k} \Omega$, measured at $25{ }^{\circ} \mathrm{C}$, down-to $0.27 \mathrm{k} \Omega$ at $135^{\circ} \mathrm{C}$. On the other hand, for the gate-drain junction, its value was shown to be increased from $4.63 \mathrm{k} \Omega$ up-to $5.79 \mathrm{k} \Omega$ with increasing temperature from $25{ }^{\circ} \mathrm{C}$ up-to $135{ }^{\circ} \mathrm{C}$, respectively. Moreover, for the gate-source junction impedance, it is showed that, its value increased from $3.71 \mathrm{k} \Omega$ up-to $4.61 \mathrm{k} \Omega$, with increasing the temperature within the investigated range.

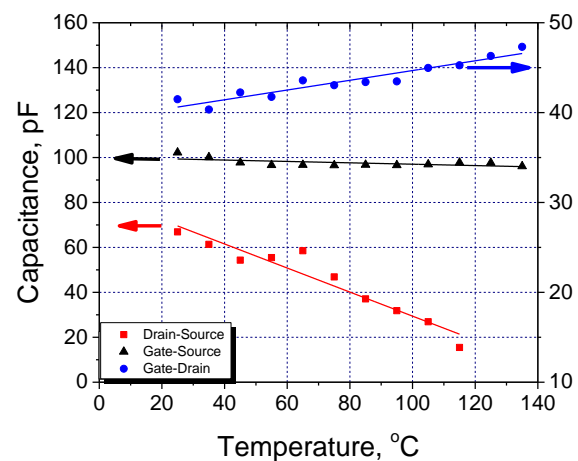

(a)

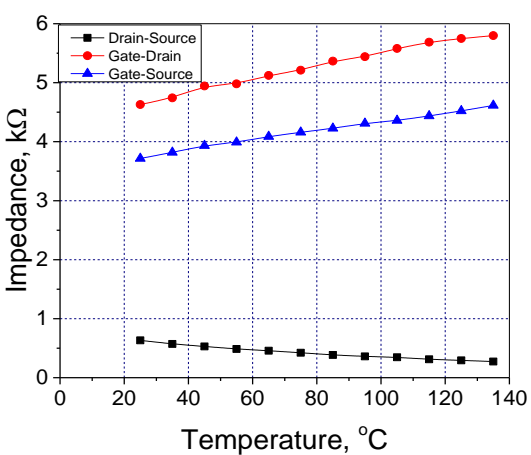

(b)

Fig. (13): Temperature dependences on the drain-source-, gate-drain- and gate-source- junctionscapacitance (a) and junctions impedance (b) for MOSFET 2N6660.

The dependence of $Q$ on temperature for the different junctions is shown in Fig. (14). From which, it is clearly shown that for drain-source junction, $Q$ value decreased from an initial value of 0.011 down-to 0.004 on increasing temperature up-to $135^{\circ} \mathrm{C}$. On the other hand, for gate-drain junction and gate-source junction, respectively Q values increased from 0.047 and 0.096, measured at $25{ }^{\circ} \mathrm{C}$ up-to 0.068 and 0.096 , at $135{ }^{\circ} \mathrm{C}$. At the same time, it is clearly shown that for drain-source junction, $\mathrm{D}$ was shown to be increased from an initial value of 93.9 up-to 450 for the same temperature levels. On the other hand, for gate-drain- and gate-source - junctions, D values decreased from the initial value of 20.6 and 10.37 , at $25{ }^{\circ} \mathrm{C}$ down-to 14.47 and 8.71 at $135^{\circ} \mathrm{C}$ [V. V. Orlov, V. A. Felitsyn, G. I. Zebrev, 2016]. 


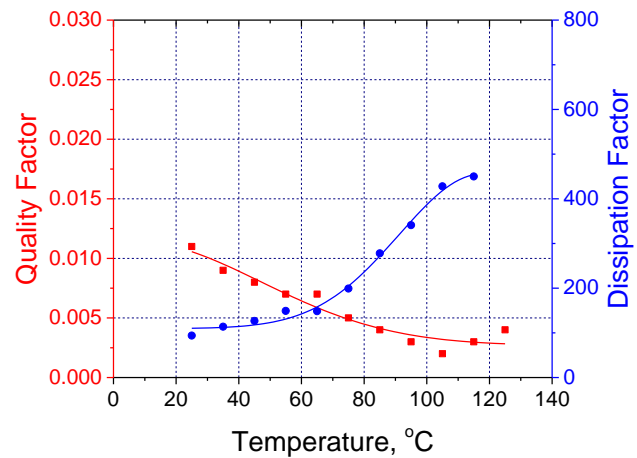

(a)

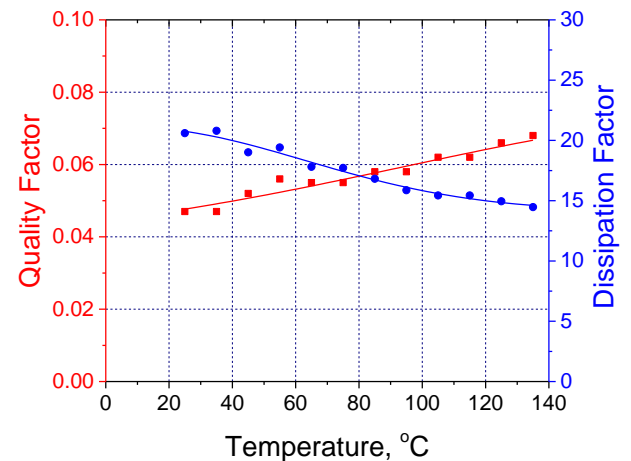

(b)

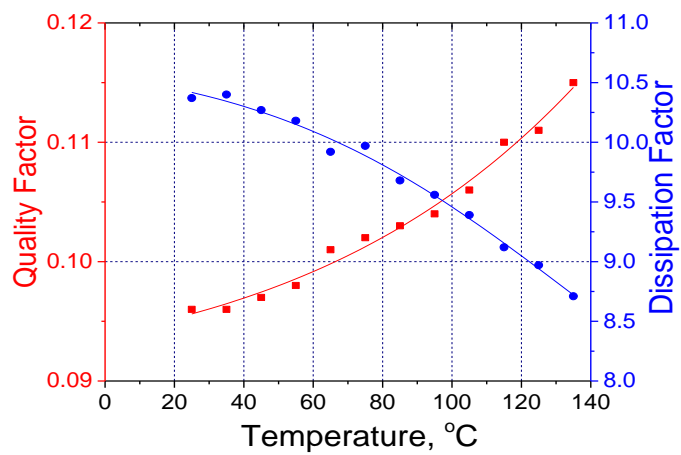

(c)

Fig. (14): Temperature dependences on the quality and dissipation factors of the drain-source (a), gatedrain (b) and gate-source (c) junctions for MOSFET 2N6660.

The dependence of $\phi$ on temperature is shown in Fig. (15), from which it is clearly shown that for drain-source junction, $\phi$ value increased from the initial value of $-0.6^{\circ}$ up-to $0^{\circ}$ on increasing the temperature from $25{ }^{\circ} \mathrm{C}$ to $135{ }^{\circ} \mathrm{C}$. On the other hand, for gate-drain and gate-source junctions, $\phi$ values decreased from the initial values of $-2.8^{\circ}$ and $-5.5^{\circ}$ down-to $-3.8^{\circ}$ and $-6.5^{\circ}$ at $25^{\circ} \mathrm{C}$ and $135^{\circ} \mathrm{C}$, respectively.

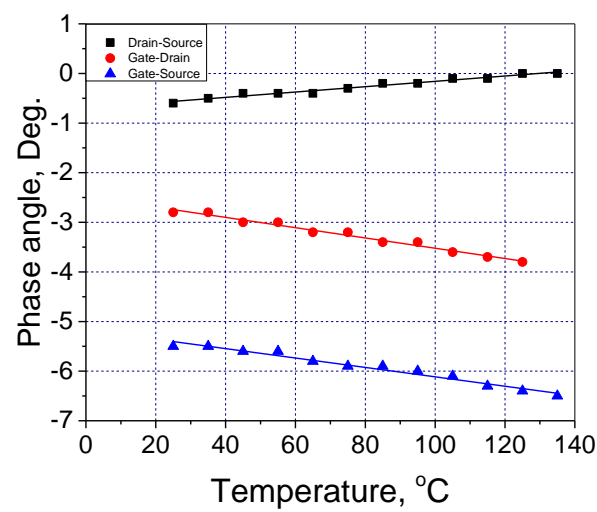

Fig. (15): Temperature dependences of the drain-source, gate-drain- and gate-source- phase angles for MOSFET 2N6660.

\subsection{Conclusions}

From the study, experimental work, results, analysis and discussions, it could be concluded that temperature dependence of the electrical characteristics of BJTs and MOSFETs is a great interest, where severe effects were registered. So, carefully selected transistor and its temperature level is very important for electronic systems design. 


\section{References:}

1. A. S. Sedra, K. C. Smith "Microelectronic circuits", 5 ${ }^{\text {th }}$ Ed. , Ch. 5, pp. 377-517, New York, Oxford university, 2004.

2. A. Osman and M. A. Osman, "Investigation of High Temperature Effects on MOSFET Transconductance $\left(\mathrm{g}_{\mathrm{m}}\right)$ ", IEEE, the $4^{\text {th }}$ Intr. High Temp. Electr. Conf., INSPEC Accession No. 611441, pp.301-304, 1998.

3. B. Eslamia and S. Ashrafib, "Effect of gamma ray absorbed dose on the FET transistor parameters", Results in Physics, Vol. 6, pp. 396-400, 2016. https://doi.org/10.1016/j.rinp.2016.07.003

4. B.L. Theraja and A.K. Theraja, "A.T.B. of Electrical Technology", Chs. 57 and 63 pp. 2187-2218 and 2188-2218, 2008.

5. E. Schurackm, et al, "Nonlinear effects in transistors caused by thermal power feedback: simulation and modeling in spice", Proc. IEEE Intr. Symposium on Circuits and Systems, Vol.6, pp.879-882, 1992.

6. H. Djelti, et al, "Two dimensional numerical simulation of temperature dependency of MOSFET out-put characteristics”, IEEE, STIC Lab., 2008.

7. H. Mnif, et al, "A new approach for modeling the thermal behavior of bipolar transistors", IEEE, $4^{\text {th }}$ Intr. Caracas Conf. on Devices, Circuits and Systems, pp. DO241- DO24 5, INSPEC Accession No. 7374389, 2002.

8. J. Millman and C.C. Halkias, "Integrated Electronics: Analog and Digital Circuits and Systems", $3^{\text {rd }}$ Ed., Ch. 5, pp. 118-158, USA, 1972.

9. M. A. Hopcroft, et al, "Using the temperature dependence of resonator quality factor as a thermometer", Appl. Phys. Lett. 91, pp. 013505-1- 013505-3, American Institute of Physics, DOI: 10.1063/1.2753758, 2007.

10. N. Rinaldi and V. Alessandro, "Theory of electro thermal behavior of bipolar transistors", IEEE Trans. on Electronic Devices, Part I : Single-Finger Devices, Vol. 52, No.9, 2005.

11. R. M. Fox and S. G. Lee, "Predictive modeling of thermal effects in BJTs", IEEE Jour, university of Florida, pp. 98-92, 1991.

12. S. Bethi, et al, "A temperature and process insensitive CMOS only reference current generator", M.Sc. Thesis, Faculty of The University of Akron, 2014. 
13. T. D. Haeffner, "Irradiation and temperature characterization for a $32 \mathrm{NM}$ RF silicon-on-insulator CMOS process”, M.Sc. Thesis, Nashville, Tennessee, 2015.

14. "Thermal Stability of MOSFETs", Application Note, Semiconductor Components Industries, LLC, No. AND8199/D, 2014. http://onsemi.com

15. V. V. Orlov, V. A. Felitsyn and G. I. Zebrev, "Compact modeling of I-V characteristics in irradiated MOSFETs: impact of operation temperature and interface traps", IEEE, the $16^{\text {th }}$ Eurpoen Conf. on Radiation and its Effects on Components and System (RADECS), INSPEC Accession No. 17335345, 2016.

16. Y. Agiwa, et al., "Reliability study of mounting structure for high temperature power semiconductor device chip using high purity aluminum", In Proc. Thermal and Thermo mechanical Phenomena Electronic System, Orlando, FL., U.S.A, pp. $906-912,2008$ 


\section{الملخص العربى}

تأثير الحرارة على الخصائص الكهربية لنبيطتي ترانزستور ثنائي القطبية و ترانزستور تأثير المجال الأكسيدي المعدني ترني

ريهام أسامة السعيد إبراهيم(') سها محمد عبد العظيم (') صفاء محمد رشدي الغنام(') ـ فؤاد عبد المنعم سعد سليمان(") ـ ا ـ معمل أبحاث الإكترونياتـ قسم الفيزياءـ كلية البنات للأداب والعلوم والتربيةــ جامعة عين شمس ـالقاهرةجمهورية مصر العربية

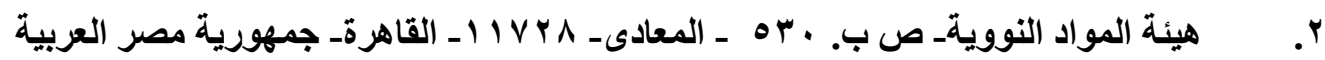

تناول البحث المعروض دراسة عملية تطبيقية على الخصائص الكهربية الاستاتيكية (منحنيات التيار والجهد )

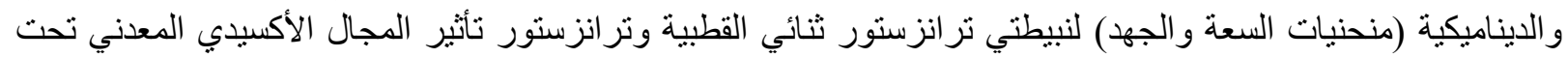
تأثير الحرارة المرتفعة ، فى المدى من درجة حرارة الغرفة أن تأثير الحرارة على ترانزستور ثنائي القطب

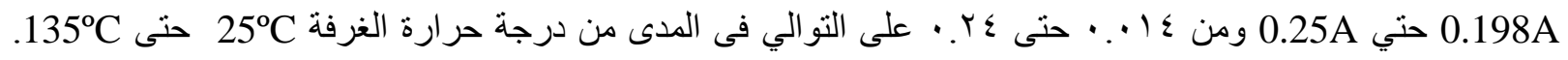

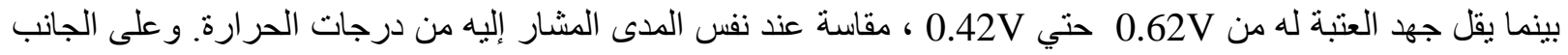

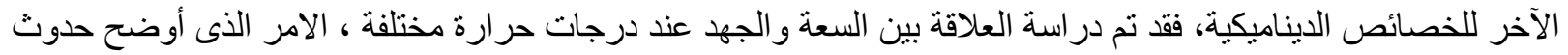

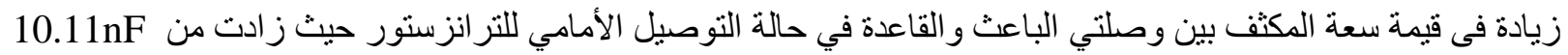
حتى 45.09nF

أما بالنسبة إلى تأثنر الحر ارة على ترانزستور تأثثر المجال الأكسيدي المعدني 2N6660 فقد تم ملاحظة حدوث اضمحلال

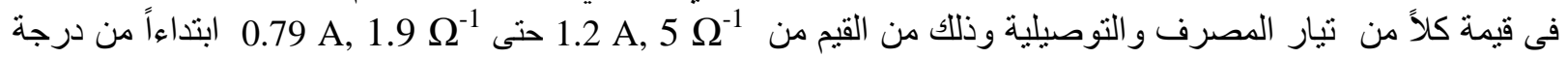

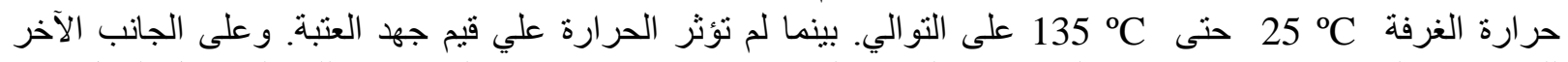

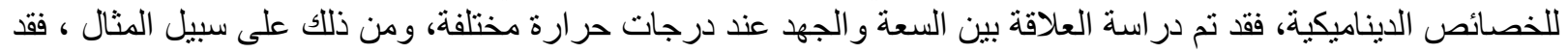

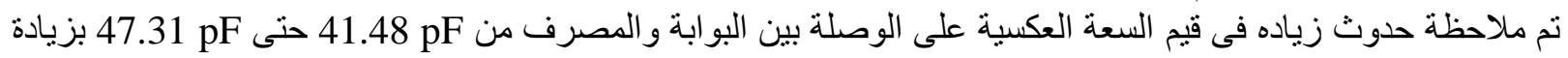
الحرارة في المدى المذكور.

\section{اسماء المشاركين بالبحث :}

1- أ.د.م./ فؤاد عبد المنعم سعد سليمان (أستاذ هندة الإكترونيات والحاسبات - ورئيس قسم الهندسة

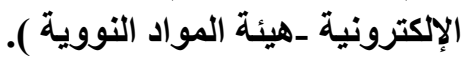

r ـ ـ./ صفاء محمد رشدي الغنام ( أستاذ مساعد الإليكترونيات ـ قسم الفيزياء ـ كلية البنات للآداب والعلوم

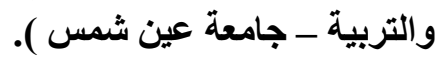

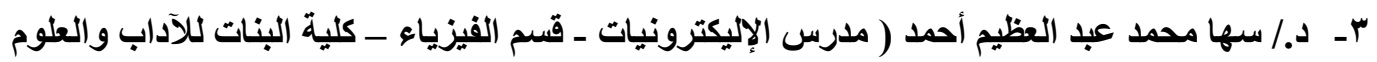

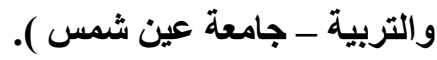

ع - ريهام أسامة السعيد إبراهيم ( باحثة ماجستير ـ قسم الفيزياء ـ كلية البنات للآداب والعلوم والتربية ـ جامعة عين شمس ). 